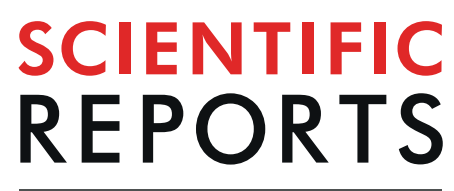

natureresearch

\title{
OPEN
}

Published online: 07 February 2020

\section{Publisher Correction: Propolis- based niosomes as oromuco- adhesive films: A randomized clinical trial of a therapeutic drug delivery platform for the treatment of oral recurrent aphthous ulcers}

\author{
Mona G. Arafa, Dalia Ghalwash, Dina M. El-Kersh \& M. M. Elmazar \\ Correction to: Scientific Reports https://doi.org/10.1038/s41598-018-37157-7, published online 21 December \\ 2018 \\ The original version of this Article contained an error in Affiliation 3, which was incorrectly given as 'Department \\ of Pharmacognosy, The British University in Egypt (BUE), El-Sherouk city, Cairo, 11837, Egypt'. The correct \\ affiliation is listed below:
}

Department of Pharmacognosy, Faculty of Pharmacy, The British University in Egypt (BUE), El-Sherouk city, Cairo, 11837, Egypt

This error has now been corrected in the HTML and PDF versions of the Article.

(c) (1) Open Access This article is licensed under a Creative Commons Attribution 4.0 International License, which permits use, sharing, adaptation, distribution and reproduction in any medium or format, as long as you give appropriate credit to the original author(s) and the source, provide a link to the Creative Commons license, and indicate if changes were made. The images or other third party material in this article are included in the article's Creative Commons license, unless indicated otherwise in a credit line to the material. If material is not included in the article's Creative Commons license and your intended use is not permitted by statutory regulation or exceeds the permitted use, you will need to obtain permission directly from the copyright holder. To view a copy of this license, visit http://creativecommons.org/licenses/by/4.0/.

(c) The Author(s) 2020 